\title{
Microbiostratigraphy, microfacies and sequence stratigraphy of upper cretaceous and paleogene sediments, Hendijan oilfield, Northwest of Persian Gulf, Iran
}

\author{
Bahman Soleimani $^{1}$, Alireza Bahadori ${ }^{1^{*}}$, Fanwei Meng ${ }^{2}$ \\ ${ }^{1}$ Department of Geology, Faculty of Earth Sciences, Shahid Chamran University, Ahvaz, Iran; \\ *Corresponding Author: bahadorialireza@yahoo.com \\ ${ }^{2}$ State Key Laboratory of Paleobiology and Stratigraphy, Nanjing Institute of Geology and Paleontology, Chinese Academy of Sci- \\ ences, Nanjing, China
}

Received 30 July 2013; revised 30 August 2013; accepted 7 September 2013

Copyright (c) 2013 Bahman Soleimani et al. This is an open access article distributed under the Creative Commons Attribution License, which permits unrestricted use, distribution, and reproduction in any medium, provided the original work is properly cited.

\section{ABSTRACT}

Hendijan oilfield is located on Northwest of Pesian Gulf offshore of Iran and geologically in the Dezful embayment. In this study, the paleosedimentary depositional environment of the Early Cenomanian to Late Eocene deposits of the Sarvak, Ilam, Gurpi, Pabdeh and JahrumPabdeh Formations was evaluated using microbiostratigraphy, microfacies and D-INPEFA curves which are an accurate method in sequence stratigraphy in terms of regression and transgression of the sea. Also, we used limited elemental geochemical data of oxygen and carbon isotopes in compare with palaeontological data to infer the upper part, $\mathbf{1 0} \mathrm{m}$, of the Sarvak Formation. Statistical correlation analyses of geochemical data from upper part of the Sarvak Formation enable inference of differences in paleoconditions at this part and Sarvak Formation, and another Formation, llam, was distinguished. Palaentilogical analysis using planktonic foraminifera and calcareous nannofossils enables inference about time scale of each Formation. Petrographic data and different sediment textures support those inferences resulted from Gamma ray logs as D-INPEFA curves about different paleo-conditions that occurred during the development of the studied Formations. Synthesis of the analyses leads to the final interpretation that upper Cretaceous, Sarvak, Ilam and Gurpi Formations, at the Hendijan oil field were formed in a carbonate ramp that was likely closed to the open sea, where Gurpi Formation was deposited, by a shallow barrier that allowed seawater recharge into the basin and deep marine basin where Paleogene sediments, Pabdeh and Jahrum-Pabdeh, were deposited.

Keywords: Upper Cretaceous; Paleogene;

Planktonic Foraminifera; Microfacies; Sequence

Stratigraphy; Hendijan Oil Field (SW Iran)

\section{INTRODUCTION}

The Persian Gulf Basin is elongate, margin sag-interior sag, sedimentary basin spanning the last $650 \mathrm{Ma}$ along the northeastern subducting margin of the Arabian Plate and is the largest basin with active salt tectonism in the world. This basin is asymmetrical in NE-SW cross section with sediments thickening from $4500 \mathrm{~m}$ near the Arabian Shield to 18,000 m beside the Main Zagros Reverse Fault. In fact, this basin is situated in the offshore area of Zagros Fold Belt [1]. It is the richest region of the World in terms of hydrocarbon resources and Persian Gulf's oil fields are among the best oil fields in the worlds. Oil fields such as Sorush, Hendijan, Bahregansar, Nowruz and Lavan are the most important Iranian oil fields located at the Persian Gulf. According to different estimates, the basin contains $55 \%$ to $68 \%$ of recoverable oil reservoirs and more than $40 \%$ of gas reservoirs [2]. The basin is located at the junction of the Arabian Shield and Iranian continental block that belong to two different (Arabian and Eurasian) lithospheric plates. Collision of these plates at the Mesozoic/Cenozoic boundary produced the Zagros Fold Belt extending for about 2000 km 
from southeastern Turkey through northern Syria and Iraq to western and southern Iran, and with its numerous supergiant hydrocarbon fields, there are the most resource-prolific fold-thrust belt of the world and the large Mesopotamian Foredeep, which is a member of the Persian Gulf Basin [3]. During the most part of the Phanerozoic, this basin belonged to an ancient passive margin of Gondwana, which was opened toward the Paleotethys Ocean in the Paleozoic and toward the Neotethys in the Mesozoic. Stable subsidence and the unique land-scapeclimatic conditions favored the accumulation of very thick sediments [4] (Figure 1).

Sarvak Formation is a thick carbonated unit deposited in Neothetys Southern Margin of Zagros area. In the past this rock unit was called Hipporite limestone, Rudist limestone and Leshtegan limestone, but with sectional measurement in Sarvak rock unit at Bangestan Mountain, Sarvak Formation substituted former names [5]. Based on identified fossils, the age of the Sarvak Formation is considered Upper Albin to Turonian in type section. This formation mostly includes carbonate in lithology and was composed from sequence of thin to medium-bedded limestone and massive limestone. The lower lithostratigraphic limit of Sarvak Formation which is conformable and gradational overlies the Kazhdumi Formation in type section. Upper lithostratigraphic limit of that is secant with Ilam or in some places with Gurpi Formation. Also Sarvak Formation is one of the most important hydrocarbon resources production horizons in Iran [6].

The Ilam Formation (Santonian to Campanian), which is part of the Bangestan Group, mainly consists of fossi liferous limestone [7]. The type section of the Ilam Formation is situated in the Kabirkoh area, Lurestan, and is overlain by the Surgah Formation and underlain by the Gurpi Formation [5].

However, in the Hendijan oil field conformable with and without any recognizable boundary, the Ilam Formation, overlying the Sarvak Formation, is locally unrevealed. This formation is determined with its 190 meter thickness of light gray clay limestone which has became white in effect of weathering, its regular bedding surfaces and some thin shale layers between the limestones.

Gurpi Formation developed in Fold Zagross in Provinces Khuzestan, Lorestan and Fars. Age sediment was reported in restricts stage of santonian to maastichtian. The name of this formation was derived of Kuh-e-Gurpi in province Khuzestan, in local type section in north square oil Lali in north-east Masjed-Soleiman composed of $320 \mathrm{~m}$ argillaceous limestone, with shale and gray marl tending to blue. The Gurpi Formation overlies the Ilam Formation and is disconformably overlain by the Pabdeh Formation [5].

Pabdeh Formation as one of the oil source rocks in Zagros has drawn the attention of most geologists since a long time ago. The name of Pabdeh Formation (Paleocene to Early Miocene) is obtained from Pabdeh Mountain in Khuzestan Province where James and Wynd [7] described the type section at Tang-e Pabdeh in south east of Pabdeh Mountain which is located in north of Lali oil field. The formation is known in outcrop and in subsurface in the provinces of Khuzestan, Fars and Lurestan of Iran. Thickness of this Formation in type section is 798.5 m. Pabdeh Formation overlies Gurpi Formation disconformably and it contains purple shale, shales and clay limestones, clay limestones with cherty nodules and dark shales [5].

The type section of Jahrum Formation is chosen in the kuh-e-Jahrum which is located near the Jahrum town in the South of Shiraz [5]. The lowest lithostratigraphic limit of the Jahrum Formation overlays the Sachun Formation and it underlays in Asmari Formation succession with an erosional disconformity. Based on James and

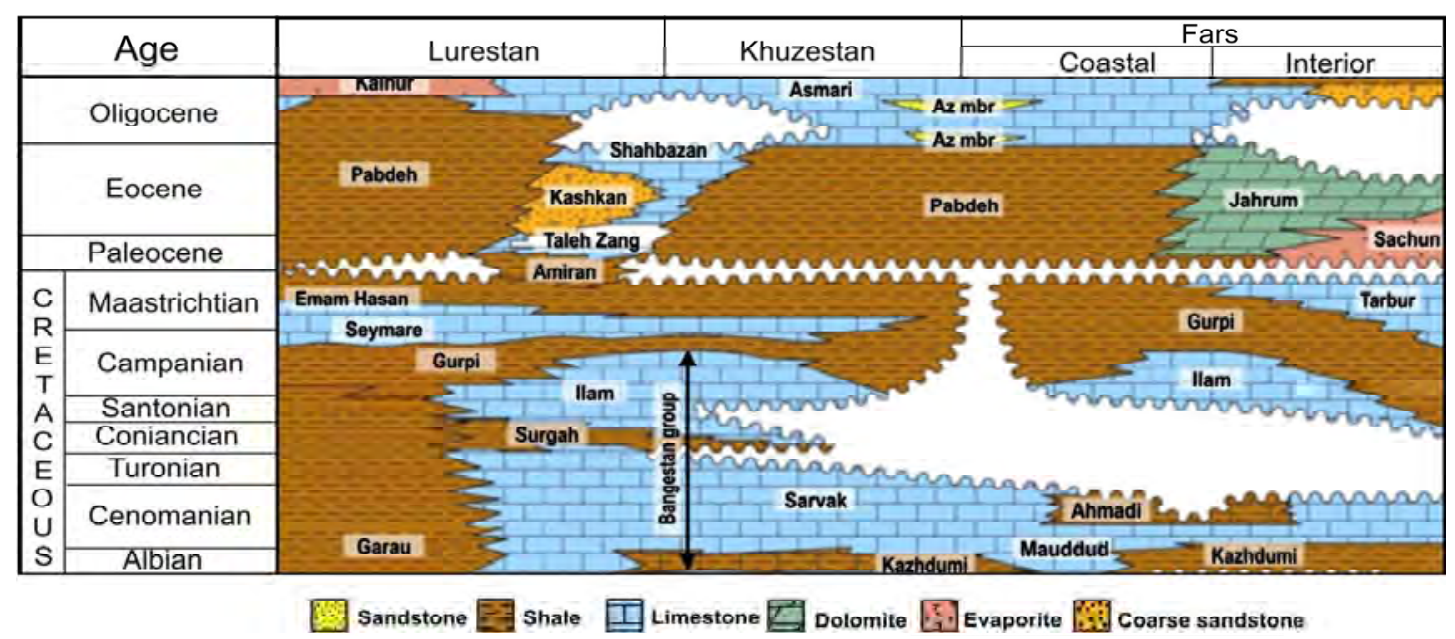

Figure 1. Mesozoic-Cenozoic stratigraphy correlation chart of the Iranian Sector of the Zagros basin showing the lateral lithology and facies changes (adapted from James and Wynd [7]). 
Wynd [7] studies, the age of the Jahrum Formation is Late Paleocene to Middle Eocene [8]. This Formation mainly consists of shale, marl and interbeds of shales and clay limestones. This Formation is overlain by the Asmari Formation.

The present study uses biostratigraphic evidence of the Cretaceous (Sarvak, Ilam and Gurpi Formations) and also Paleogene (Pabdeh and Jahrum-Pabdeh Formations) of Iran to understand the accurate biostratigraphic boundaries, unconformities and depositional facies of the relevant Formations. In addition, the geochemical evidence was used to determine the boundary between the Ilam and Sarvak Formations which are difficult to place due to similar lithologies in these Formations.

\section{STUDY AREA}

The Hendijan oil field is located in the north-west section of the Persian Gulf in offshore of Iran, south west of Iran, and geologically in the Dezful embayment (Fig- ure 2). It is about $10 \mathrm{~km}$ north-east of Bahregansar, 34 km south-west of Tangu and 42 km south-west of Rag-eSefid oilfields. This oil field was discovered in 1968 when the first well was drilled. This oil field is producing oil from 3 different reservoirs. The Sarvak Formation part of Bangestan group is considered as one of the richest petroleum reservoirs of Iran at this oil field. The structure of this oil field was influenced by two fault systems.

\section{MATERIALS AND METHODS}

\subsection{Sample Collection}

The biostratigraphy of well\# 10 at the Hendijan oil field was investigated using calcareous nannofossils and planktonic foraminifera by means of samples collected, one by one, in distances and intervals of 50 centimeters. For nannofossils investigations, smear slides of 40 samples from the well\# 10 were prepared using a small piece of sediment and a drop of distilled water. The sediment

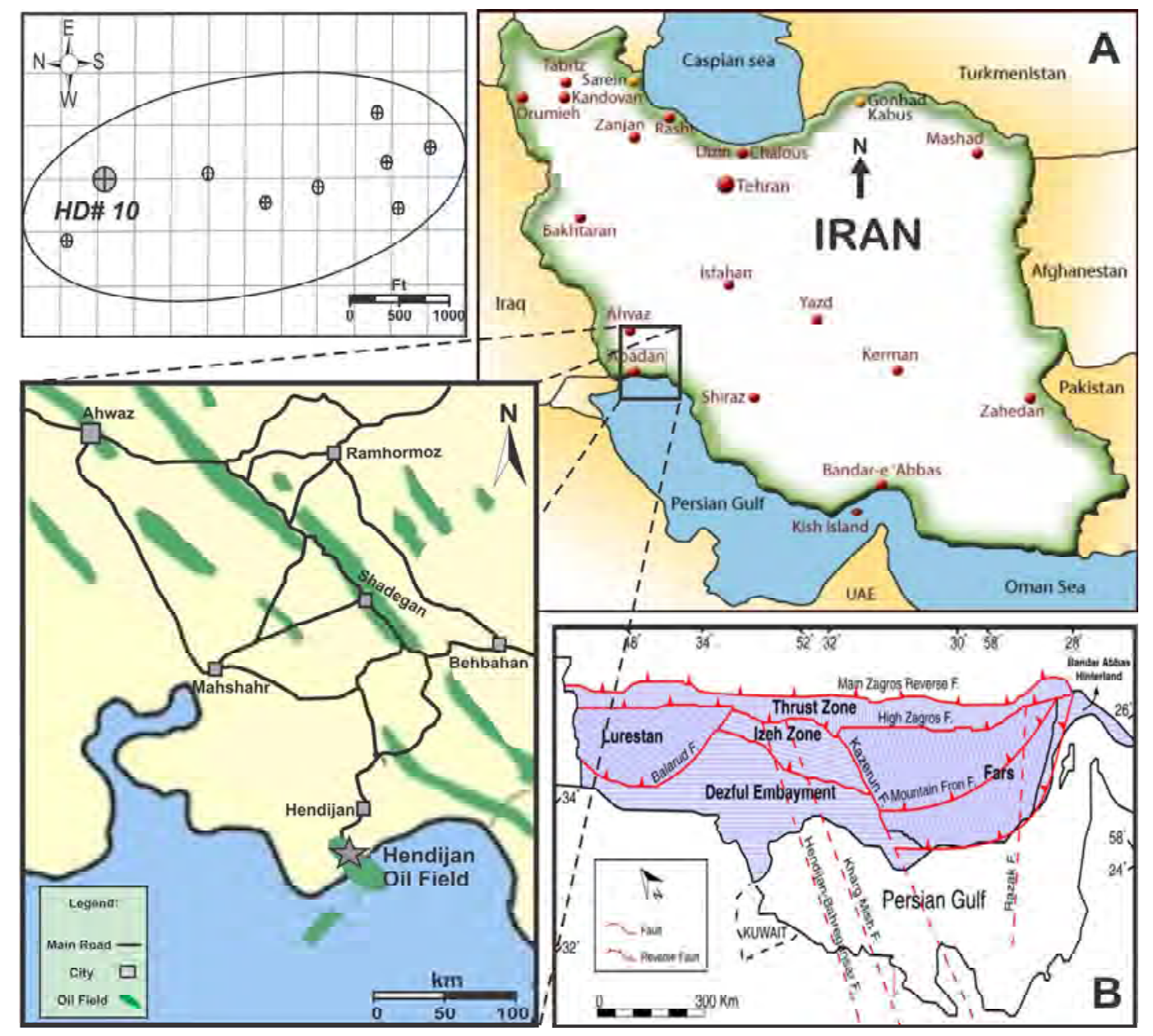

Figure 2. (A) Location map of the Hendijan oil field; (B) Main structural elements of subdivisions of the Zagros province, one of the eight geologic provinces of Iran (adapted from Farzipour-Saein [9]). Showing the lateral lithology and facies changes (adapted from James and Wynd [7]). 
was smeared onto a glass slide and fixed with canada balsam and then examined under the light microscope. For the foraminifer's investigation, in this study, more than two hundred samples were examined in thin section: 75 from Sarvak and Ilam Formations, 35 from Gurpi Formation and 110 from Pabdeh and Jahrum-Pabdeh Formations. Samples were disintegrated with hydrogen peroxide and washed over 63 - 150 - 300 - 600 mm sieves. The $150 \mathrm{~mm}$ and $300 \mathrm{~mm}$ size fractions were richest in planktonic foraminifera for biostratigraphic investigation. Foraminiferal assemblages were checked qualitatively. Additionally, some sections were investigated for microfacies. However, not all could be used for biostratigraphic zonations because of bad preservation or a low foraminifer's numbers.

\subsection{Samples Analysis}

The The distribution of planktonic foraminifera is given in separate figures. The biostratigraphic interpretation resulting from the composition of the planktonic foraminifera and calcareous nannofossils assemblages respectively follows the zonal scheme of James and Wynd [7] and Sissingh [10].

Also charts of sea level changes in well\# 10 were illustrated by means of Gamma ray logs and Cyclo Log 3.2 software. Using CycloLog in well analysis and well correlations is unique in its approach. It uses of a datadriven analysis of well data, followed by a model-driven interpretation using the state-of-the-art stratigraphic conceptual models. Data-driven analysis of wireline log data, especially Gamma Ray logs, in CycloLog is a mathematical calculation using spectral analysis. The results are two types of log transform curves, the PEFA and INPEFA curves, which are unique to CycloLog. PEFA shows the relative amount of change between one data-point and the next, based on the information in a window of analysis. INPEFA is the integral of PEFA. It is a cumulative plot of the changes found in the PEFA curve used to define real (bounding) surfaces and trends in well zonations and correlations. Interpretation of INPEFA curves usually requires experimenting with the depth interval over which INPEFA is calculated called Dynamic-INPEFA (D-Inpefa).

In order to determine the accurate stratigraphic boundary between Sarvak and Ilam Formations in this study ten powdered samples collected near significant biostratigraphic and to some extent lithological changes, the probable boundary, were analysed with a Micromass, Model 602 ES, for oxygen and carbon isotopes at the Nanjing Institute of Geology and Paleontology, Chinese Academy of Sciences, Nanjing, China. Fifteen mg of powdered samples were allowed to react with anhydrous phosphoric acid in reaction tubes under vacuum at $25^{\circ} \mathrm{C}$ for $24 \mathrm{~h}$. The $\mathrm{CO}_{2}$ extract from each sample was analyzed for $\delta 180$ and $\delta 13 \mathrm{C}$ by mass spectrometry. Preci- sion of data is $\pm 0.1 \%$ for both $\delta 180$ and $\delta 13 \mathrm{C}$ and these values were reported relative to PDB.

\section{RESULTS AND DISCUSSION}

\subsection{Sarvak and Ilam Formations}

\subsubsection{Biostratigraphy of Sarvak Fm.}

Biozones determined by James \& Wind [7] for Zagros region of Iran are consisted of 66 biozones. These biozones are based on the appearance of different planktonic foraminifera at the stratigraphic column of Zagros Formation with age range of Triassic to Pliocene.

The thickness of Sarvak Formation is varied from 90 to 115 meters at the Hendijan wells. In these wells Sarvak Formation is overlain by the Ilam Formation uncomfortably determined in this study. It is underlain the Kazhdumi Formation with conformable contact. In this oil field, Sarvak Formation has been formed of marly limestone and dolomnite with thinner interbeds of marl and limestone. Out of this, 18 genera and 26 species were determined (Figure 3). Based on the obtained foraminifera, in the studied section, Saevak Formation is Early Cenomanian to Turoninan in age that corresponding to Favusella washitensis acro zone (23), Oligostegina facies (26, 26b) biozones of James \& wind [7].

Principal index planktonic foraminifers, identified based on James and Wynd [7], Alegret \& Thomas [11], Gibson [12], khosrotehrani [13], Loeblich \& Tappan [14] within the Sarvak Formation at this oil field, are as below:

Biticinella berggiensis, Calcisphaerula innominata, Dicarinella primitive, Dicarinella canaliculata, Favusella washitensis, Globigerinelloides algeriana, Globigerinelloides sp., Globigerinelloides ferreolensis, Hedbergella delroiensis, Hedbergella planispira, Hedbergella sp., Heterohelix reussi, Heterohelix sp., Lenticulina sp., oligosteginids, Praeglobotruncana sp., Rotalipora Cushmani, Rudist fragment, Stomiosphaera sphaerica (Figure 4).

\subsubsection{Introducing Biozonation of Sarvak Fm.}

Actually, in the studied stratigraphic section, considering microbiostratigraphic studies three biozones have been determined for identified foraminifers in the sediments of the Sarvak Formation which are as follow:

1) Biozone No. 1-Favusella washitensis acro zone (23) [7]: The thickness of this biozone at the beginning of the Sarvak Formation in Hendijan Section is $12.5 \mathrm{~m}$ (from depth 3039.5 to $3052 \mathrm{~m}$ ) and its microfossils include: Favusella washitensis, Hedbergella delroiensis, Hedbergella planispira, Lenticulina sp., Oligosteginid, Which indicates the age of Albian to Early Cenomanian.

2) Biozone No. 2-Oligostegina facies (26) [7]: This biozone determined in the middle of the Sarvak Forma- 


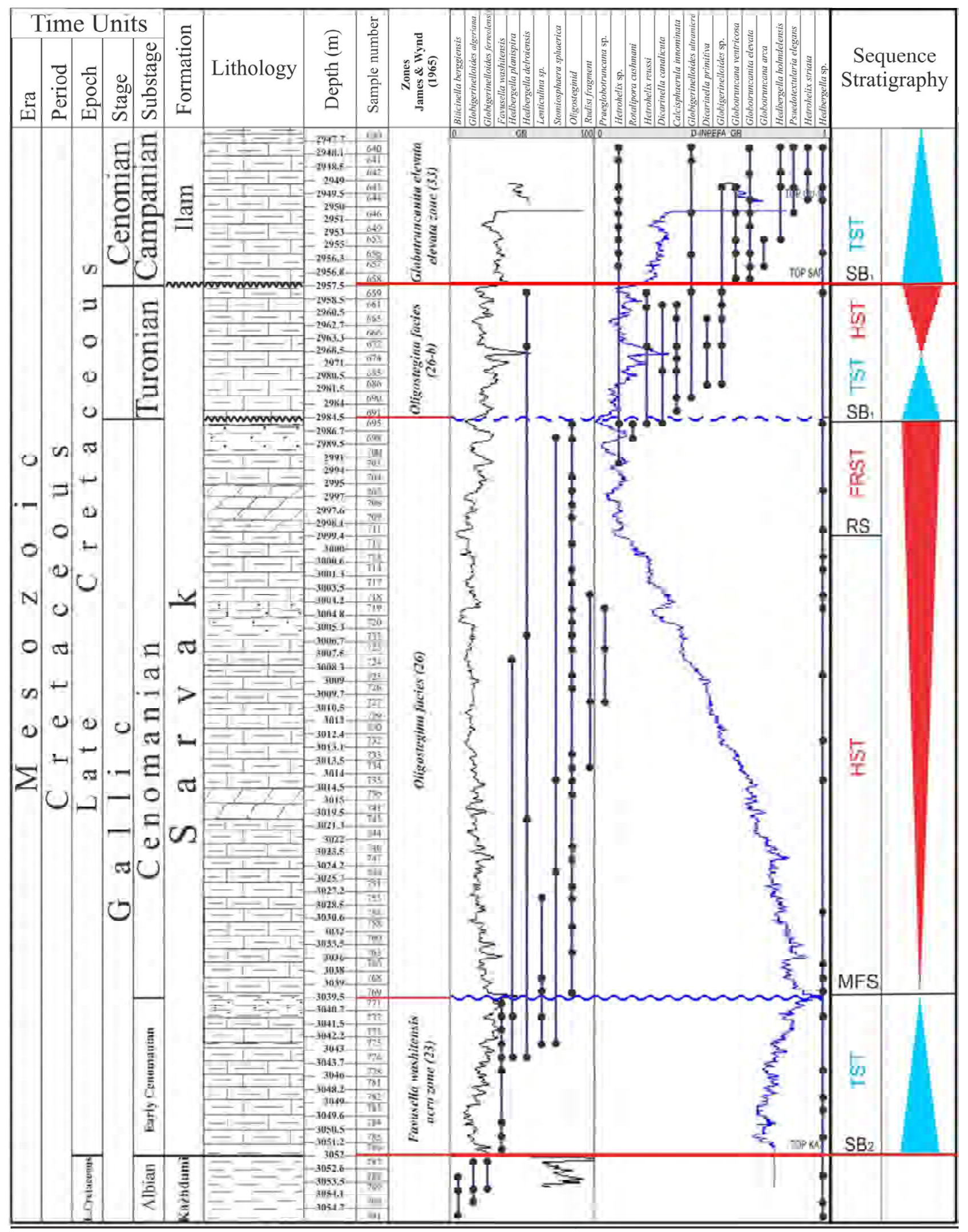

Figure 3. Stratigraphic column, Planktonic foraminiferal distribution and sequence stratigraphy of the Sarvak and Ilam Formations from the Well\# 10 at the Hendijan oil field. 


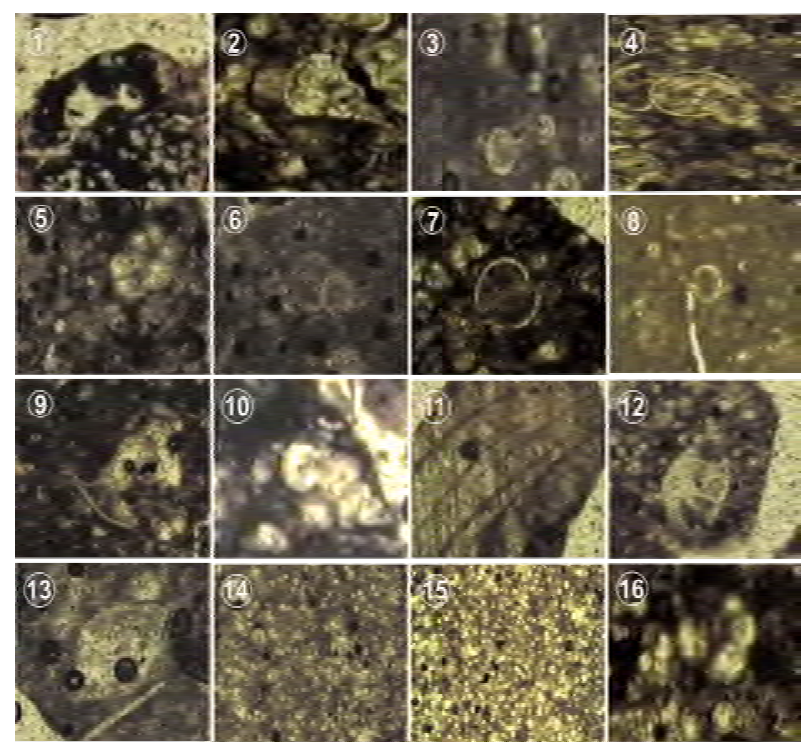

Figure 4. All figures in PPL light micrographs at $200 \times$ magnification; 1. Globigerinelloides ferreolensis; 2. Heterohelix reussi; 3. Hedbergella planispira; 4. Hedbergella sp.; 5. Biticinella berggiensis; 6. Favusella washitensis; 7,8. Stomiosphaera sphaerica; 9. Dicarinella canaliculata; 10. Rotalipora Cushmani; 11. Rudist fragment; 12,13. Lenticulina sp.; 14,15. Oligosteginid; 16. Globigerinelloides ferreolensis.

tion includes the sediments of Middle to Late Cenomanian. The thickness of this biozone is $55 \mathrm{~m}$ (from depth 2984.5 to $3039.5 \mathrm{~m}$ ) and its organic constituents includes: Oligosteginids, Favusella washitensis, Hedbergella delroiensis, Hedbergella planispira, Lenticulina sp., Rudist fragment, Praeglobotruncana sp.

3) Biozone No. 3-Sub zone Oligostegina facies (26-b) [7]: This biozone includes Turionian sediments in the studied stratigraphic section of the Sarvak Formation. The thickness of this biozone is $27 \mathrm{~m}$ (from depth 2957.5 to $2984.5 \mathrm{~m}$ ) and its microfossils include: Calcisphaerula innominata, Dicarinella primitive, Dicarinella canaliculata, Heterohelix reussi, Globigerinelloides ultramicra. It should be considered that as the subzone Oligostegina facies (26-a) of late Cenomanian age is absent, it can be inferred that Late Cenomanian sediments are missing due to an unconformity at the beginning of this biozone. So, the uppermost interval of the Sarvak Formation, with thickness of nearly $27 \mathrm{~m}$, appears to be deposited after the time of this unconformity.

\subsubsection{Biostratigraphy of the Ilam Fm.}

Because the Rotalia sp.-algae assemblage zone (30) and the Globotruncana concavata-Globotruncana ventricosa carinata assemblage zone (32) of James and Wynd [7] cannot be recognized within the Sarvak Formation, it can be inferred that a major unconformity occurred during the Coniacian to Santonian. Based on the index planktonic foraminifers such as Globigerinelloides ul- tramicra, Globotruncana ventricosa, Globotruncanita elevata, Globotruncana arca, Hedbergalla holmdelensis, Hetrohelix striata, Pseudotextularia elegans (Figure 4) that are identified between the depth of 2947 to $2957.5 \mathrm{~m}$, in marly limestone interbedded with thin layers of limestone and shale, the biozone Globotruncanita elevata elevata zone (33) of James and Wynd [7] can be recognized. This biozone with thickness of $10.5 \mathrm{~m}$ includes all sediments of Early Campanian age in the studied stratigraphic section of the Hendijan oil field considered as Ilam Formation (Figure 3).

\subsubsection{Recognition of Boundary Between Ilam and Sarvak Fms. Using Geochemical Analysis (Oxygen and Carbon Isotopes)}

Due to their similar lithology, the recognition of the exact boundary between the Ilam and Sarvak Formations in the study area is difficult, and it is not possible to determine the precise boundary between these two Formations based only on biostratigraphy. The carbon and oxygen isotopes compositions of Ilam and Sarvak Formations were used to determine the exact boundary.

Mean $\delta^{18} \mathrm{O}$ values for the Sarvak Formation (-3.5\% PDB) are distinctly lighter than mean $\delta^{18} \mathrm{O}$ values of the Ilam Formation (-2.7\% PDB). Thus, this difference can be used to recognize the boundary between the Ilam and Sarvak Formations within the stratigraphic succession [9] (Figure 5).

In a similar way, $\delta^{13} \mathrm{C}$ values can also be used for the recognition of the stratigraphic boundary between the two formations [15]. All carbon isotope values are positive in the Ilam Formation, in contrast to negative $\delta^{13} \mathrm{C}$ values in the Sarvak Formation (Figure 5(B)). The C-O isotope data indicate clearly that this is due to subae-
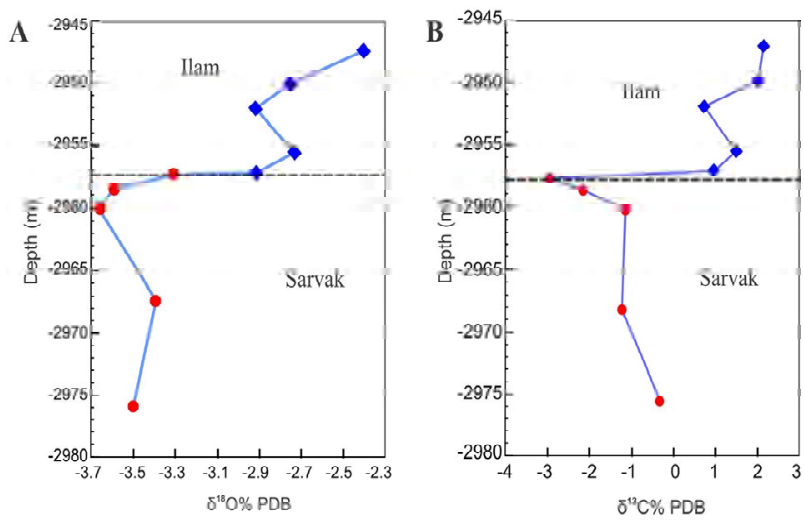

Figure 5. (A) Variation of $\delta^{18} \mathrm{O}$ along the stratigraphic column of Ilam and Sarvak Formations; (B) Variation of $\delta^{13} \mathrm{C}$ along the stratigraphic column of the Ilam and Sarvak Formations. Note that the oxygen and carbon isotope data indicate that Ilam carbonates have stabilized in the marine phreatic environment, while the negative $\delta^{13} \mathrm{C}$ values of Sarvak Formation indicate a subaerial exposure surface, below which meteoric diagenesis influenced the upper few metres of the Sarvak Formation. 
rial exposure in which meteoric diagenesis affected (at least) the upper few meters of the Sarvak Formation $[10,11]$.

The least-altered carbonate sample, with a $\delta^{18} \mathrm{O}$ value of $-2.4 \%$ PDB, was used to calculate a temperature during the relatively shallow burial, using the equation of Anderson and Arthur [16]:

$$
\mathrm{T}\left({ }^{\circ} \mathrm{C}\right)=16-4.14\left(\delta_{\mathrm{C}}-\delta_{\mathrm{W}}\right)+0.13\left(\delta_{\mathrm{C}}-\delta_{\mathrm{W}}\right)^{2}
$$

where $\mathrm{T}$ is temperature (in ${ }^{\circ} \mathrm{C}$ ), $\delta_{\mathrm{C}}$ is the heaviest oxygen isotope value in the studied samples and $\delta_{\mathrm{W}}$ is the oxygen isotope value of marine water in the Cretaceous (in SMOW), i.e. $-1 \%$ SMOW [9]. This calculation gives an early shallow burial fluid temperature of about $24^{\circ} \mathrm{C}$.

The $\delta^{18} \mathrm{O}$ values in the Ilam limestone range from $-2.4 \%$ o to $-2.95 \%$ PDB (mean $-2.7 \%$ PDB), whereas $\delta^{13} \mathrm{C}$ values range from $0.8 \%$ to $2.3 \%$ PDB (mean $1.5 \%$ PDB). The $\delta^{18} \mathrm{O}-\delta^{13} \mathrm{C}$ values from the Ilam Formation suggest diagenetic alteration in a marine phreatic setting (Figure 6).

By and large, it can be clearly inferred from the determined boundary near the top of the Sarvak Formation using foraminifera and geochemistry that about $10 \mathrm{~m}$ of strata assigned to the upper part of Sarvak Formation where it is overlain by Gurpi Formation is definitely Ilam Formation instead. This has caused many problems during well drilling.

\subsubsection{Sequence Stratigraphic Description of Sarvak Fm. in Well\# 10 of Hendijan Oil Field Using Dynamic-INPEFA Curves of Cyclolog Software}

Based on the System Tracts and the sequence strati-

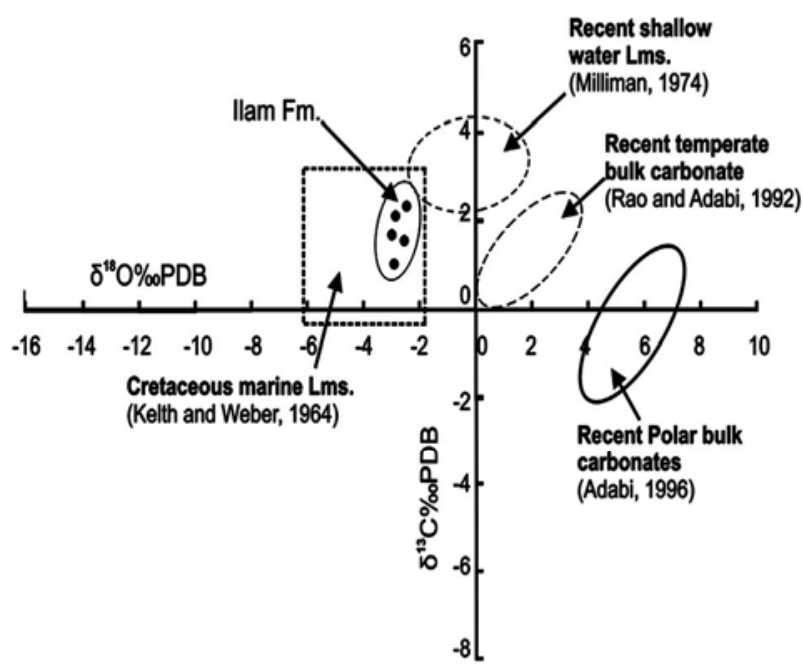

Figure 6. Comparison of $\delta^{18} \mathrm{O}$ and $\delta^{13} \mathrm{C}$ values of the Ilam carbonates with recent polar bulk carbonates [17], recent temperate bulk carbonates [18], recent shallow water limestone [19]. graphic studies resulted from using Gamma Ray log of well\# 10 of the Hendijan oil field, the sediments of the Sarvak Formation include two third order sediment sequences (Sequences No. $1 \&$ No. 2).

The first sequence with sequence boundary of SB2 type is placed on Kazhdumi Formation and the upper lithostratigraphic limit of the mentioned sequence is of SB1 sequence lithostratigraphic limit type which is placed under upper part of Sarvak Formation and the second sequence with sequence boundary of SB1 type distinctive with erosional surface disconformity as a result of Orogenic phase activity is placed on middle part of Sarvak Formation and the upper lithostratigraphic limit of the mentioned sequence is of SB2 sequence lithostratigraphic limit type which is placed under Ilam Formation. Most Forwarding Surface (MFS) is observed in the studied section of medium to thin-bedded limestone with shale $[20,21]$. The mentioned sequences encompass HST and TST facies sets. Actually, based on TST \& HST facies (Sequence No. 1) the Sarvak Formation is Early to Late Cenomanian and based on TST \& HST Facies (Sequence No. 2) this is Turonian (Figure 3).

\subsubsection{Depositional Environment and Microfacies of Sarvak Formation}

As exact evaluation of reservoir rocks is possible through of microfacies depositional environment and reservoir characterization analysis, by this way, well\# 10 of the Hendijan oil field with the mentioned aims was considered and evaluated. The microfacies analysis of cutting samples of the Sarvak Formation in Hendijan oil field is led to recognition seven microfacies of four facies belts (depositional environments) based on Flugel [22] including open marine (A), bar (B), lagoon (C) and tidal flat (D) environment. The vertical changes survey and comparing it with modern and old depositional environments indicate that the facies of the Sarvak Formation in the studied section have been deposited in a carbonate ramp.

Open marin facies zone (A) consists of bioclast plagic foram (Oligostginid) mudstone (A1), Plagic foram wackestone (A2), Intraclast bioclast packstone including Rudist and a matrix of micrite (A3). This facies zone is characterized with pelagic forams such as Hedbergella, Oligosteginid and to some extent Echinoid fragments which indicates deep open marine setting [23]. High frequency of Oligosteginid and Hedbergella suggests a very good nutrient condition in the presence of the sparse lime mud in matrix represent low energy environment in this facies zone [24-28]. The specific faunal assemblage in this facies zone can survive in normal saline open marine condition $[22,29,30]$. In sammrized, presence of high amount of lime mud suggests a calm realm with no agitation (Figures 7(A1), (2), (3)). Bar facies zone (B) 


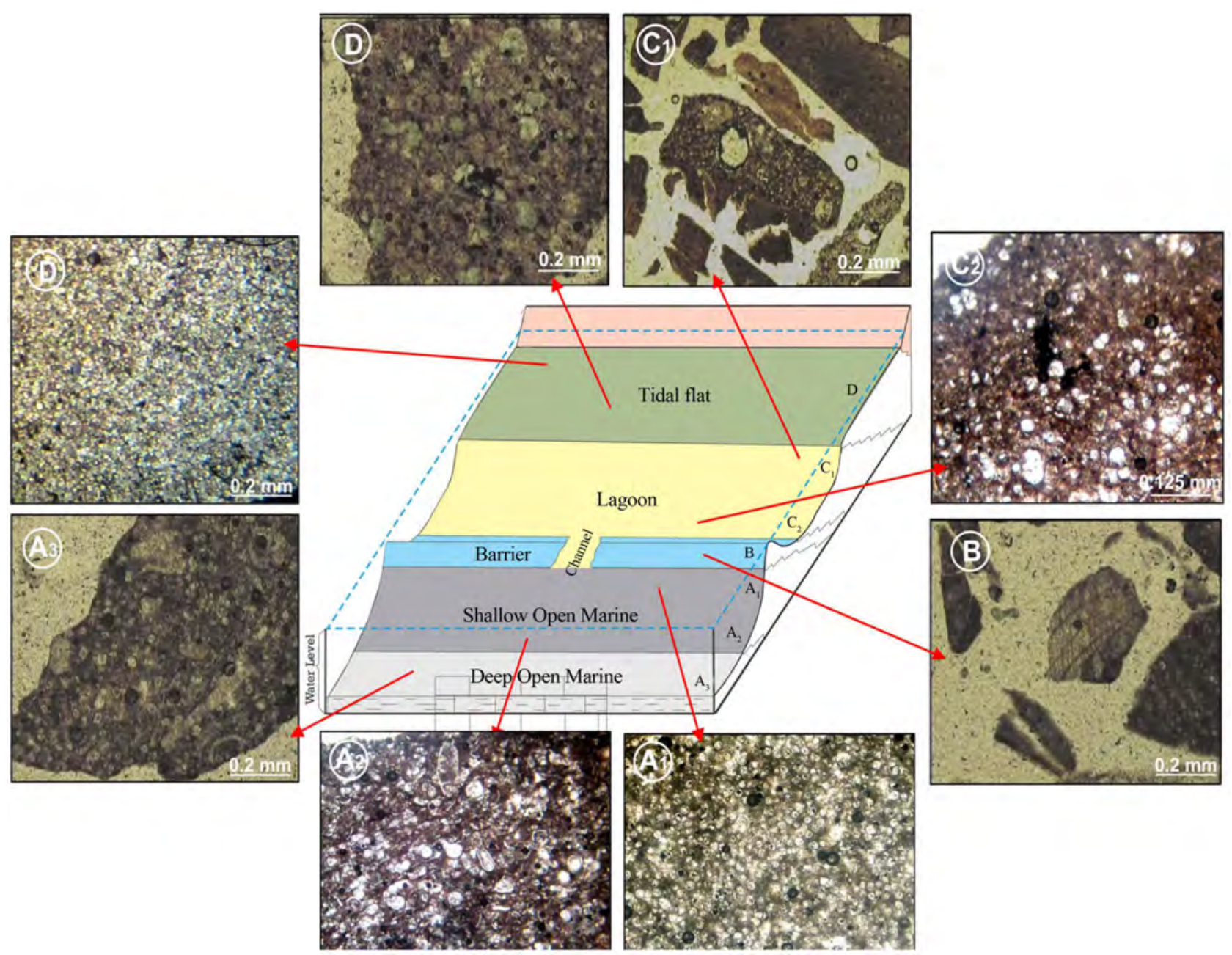

Figure 7. Depositional model of the Sarvak Formation at the Hendijan oil field; the interpretation is based on Flugel [22]. Open marin facies zone: (A1) Bioclast plagic foram (Oligostginid) mudstone, (A2) Plagic foram wackestone, (A3) Intraclast bioclast packstone ; Barrier facies zone: (B) Rudist grainstone; Lagoon facies zone: (C1) Bioclast intraclast Rudist packstone, (C2) Bioclast wackestone; Tidal flat facies zone: (D) Intraclast grainstone.

consists of Rudist grainstone. This facies zone is charectrerized with aboundant Rudist. Frequency of intraclasts such as Rudist indicates a very high energy condition in barrier setting [31-33] (Figure 7(B)). Lagoon facies zone (C) cosists of Bioclast intraclast Rudist packstone (C1), Bioclast wackestone (C2). This facies zone is mainly consisted of pelagic and some benthic forams which suggest a lagoon environment in adjacent to tidal flat [34]. The skeletal allochems are abaoundant with high diversity indicating a shallow bathy met with proper saline condition and water circulation which provide a nutrient condition [35]. Low diversity of found and increasing of lime mud in some facies suggests a low energy restricted lagoon [36] (Figures 7(C1) and (C2)). Tidal flat facies zone (D) consists of intraclast grainstone. This facies zone is generally formed from grainstone which are associated with early fine dolomite. Presense of dolomitos indicate internal part of a tidal flat seeting [37].
Glauconite is also abundant in this facies (Figure 7(D)).

\subsection{Gurpi Formation}

Planktonic foraminifera and calcareous nannofossils are suitable for subdivided biostratigarphy, since they are abundant planktonic, rapidly evolving and largely cosmopolitan, especially in the late Cretaceous. According to this, the correlation between planktonic foraminifera and nannofossils of the Gurpi formation has been studied at the Hendijan oil field.

The lower limit of Gurpi Formation deposit is conformably with Ilam Formation deposit and in terms of the upper limit, this Formation is unconformity with Pabdeh Formation deposit. This Formation has been formed of dark shales with thinner interbeds of marl and limestone. Studying the thin sections of provided samples has shown dominantly biomicrite to biopelmicrite (wackstone) and sometimes micrite (mudstone) [38-40] 
all argillaceous to some extent. Small and rounded microsparitic intraclasts and spary calcite cement that fill all foraminiferal chambers are dominant features seen in thin sections. The sedimentary environment of this formation is a bathymetrical carbonate floored basin (deep shelf or basin margin) which has deposited its facies in transgressive stage.

A total of 36 samples representing the oldest and youngest strata of the $19.3 \mathrm{~m}$ succession, were collected up to the contact with the Pabdeh Formation. The most detailed sampling was performed in the intervals at $1 \mathrm{~m}$ below and above boundaries of the Gurpi Formation. From this set of samples 8 genera and 16 species of planktonic foraminifera and 13 genera and 19 species of calcareous nannofossils were determined. As a result of this study and based on the obtained calcareous nannofossils and planktonic foraminifera, the studied section is Late Campnian to Late Maastrichtian in age, that corresponding to CC23-CC25 Zones of Sissingh [10] and Globotruncanita elevata elevata zone (33) to Globotruncana stuarti-Pseudotextularia varians assemblage zone (39) of James and wind [7]. In addition, presence index species of low latitude in Gurpi Formation have shown that this sedimentary basin was located in low latitude at the time of sedimentation.

\subsubsection{Biostratigraphy of Gurpi Formation Using Calcareous Nannofossils}

Calcareous nannofossils recorded in the Cretaceous strata are believed to be appropriate means for biostratigraphic studies [41-44]. The importance of these calcareous nannofossils for correlation has been discussed at length by $[45,46]$. The examination of calcareous nannofossils of the Gurpi Formation at the Hendijan oil field enabled us to recognize some of the standard biozones defined in Mediterranean regions, especially Tethysian domain [14,42]. In Zagros basins few studies of Cretaceous calcareous nannofossils have been carried out on Gurpi Formation. Calcareous nannofossils abundances at the Gurpi Formation of the Hendijan oil field were moderate. It caused that preparing only one thin section from cuttings related to each depth had not a good result so that some times for each depth more than two thin sections were prepared. In the Late Campnian to Late Maastrichtian the biozones CC23 to CC25 were identified using the zonal scale that subdivides the upper Cretaceous to biozones $[10,41,45]$. The Marker and the most common species are illustrated in Figure $\mathbf{8}$ and are as below:

The species Eiffellithus gorkae, Arkhangelskiella cymbiformis, Watznaueria barnesae are the major components and abundant of the assemblages. Quadrum sissinghii, Arkhangelskiella speciellata, Cribrosphaerella ehrenbergii, Thoracosphaera operculata, Eiffelithus tur- risefelli, Micula swastika, Zeugrabdutus embergerii are relatively numerous. Aspidolithus parcus constrictus, Cretarhabdus conicus, Cylindralithus nudus, Eiffellithus eximius, Microrhabdulus attenuates, Micula decussate, Micula murus, Placozygus fibuliformis, Watznaueria biporta, Zeugrabdutus kerguelensis are rare (Figure 9).

Most Cretaceous nannofossil taxa became extinct below the first purple marly intercalation, a bioevent that is synchronous with the Cretaceous/Tertiary (K/T) Boundary event in low latitude areas $[7,45]$. The palaeoclimate and depth of the sedimentary basin can be explained using the index species of calcareous nannofossils. The presence of the species mentioned above in the studied samples could indicate a very deep basin and tropical climate conditions. From the records on abundance and diversity of the low-latitude species, which are known to be very useful indexes for the Late Cretaceous $[7,10]$, it is concluded that the sedimentary basin was located in low latitude and tropical environment.

\subsubsection{Introducing Biozonation of Gurpi Formation Based on Calcareous Nannofossils}

1) Biozone No. 1-Tranolithus phacelosus zone (CC23) [10]: The first nannofossil unit recorded from the shale of the Gurpi Formation is Zone CC23 defined as the interval from the last occurrence (LO) of Reinhardtites anthophrus to the LO of Tranolithus phacelosus $[14,42,45]$. Because of this fact that based on results from the samples collected from the base of the Gurpi Formation the species such as Tranolithus phacelosus and Reinhardtites anthophrus were not observed, this biozone is determined using marker events. The last occurrence (LO) of Aspidolithus parcus divided zone CC23 to subzones one of them is defined as the interval from the LO of Aspidolithus parcus parcus to the LO of Aspidolithus parcus constrictus referred to the uppermost Campanian [10]. The age of zone is Late Early Santonian. The thickness of this biozone within the Gurpi Formation at the Hendijan oil field is $4.8 \mathrm{~m}$ (from depth 2944 to $2948.8 \mathrm{~m})$.

2) Biozone No. 2-Reinhardtities levis zone (CC24) [10]: Because of the species Tranolithus phacelosus and Reinhardtites levis were not observed in the collected samples, this biozone is recognized helping merker events of LO of Aspidolithus parcus constrictus and first occurrence (FO) of Micula murus. Out of this, the next nannofossil unit recording in the shale of the Gurpi Formation defined as the interval from the LO of Aspidolithus parcus constrictu and the FO of Micula murus, which corresponds to the zones CC24, assigned to the Early Maastrichtian [10,14,46]. The thickness of this biozone is $6 \mathrm{~m}$ (from depth 2938 to $2944 \mathrm{~m})$. 


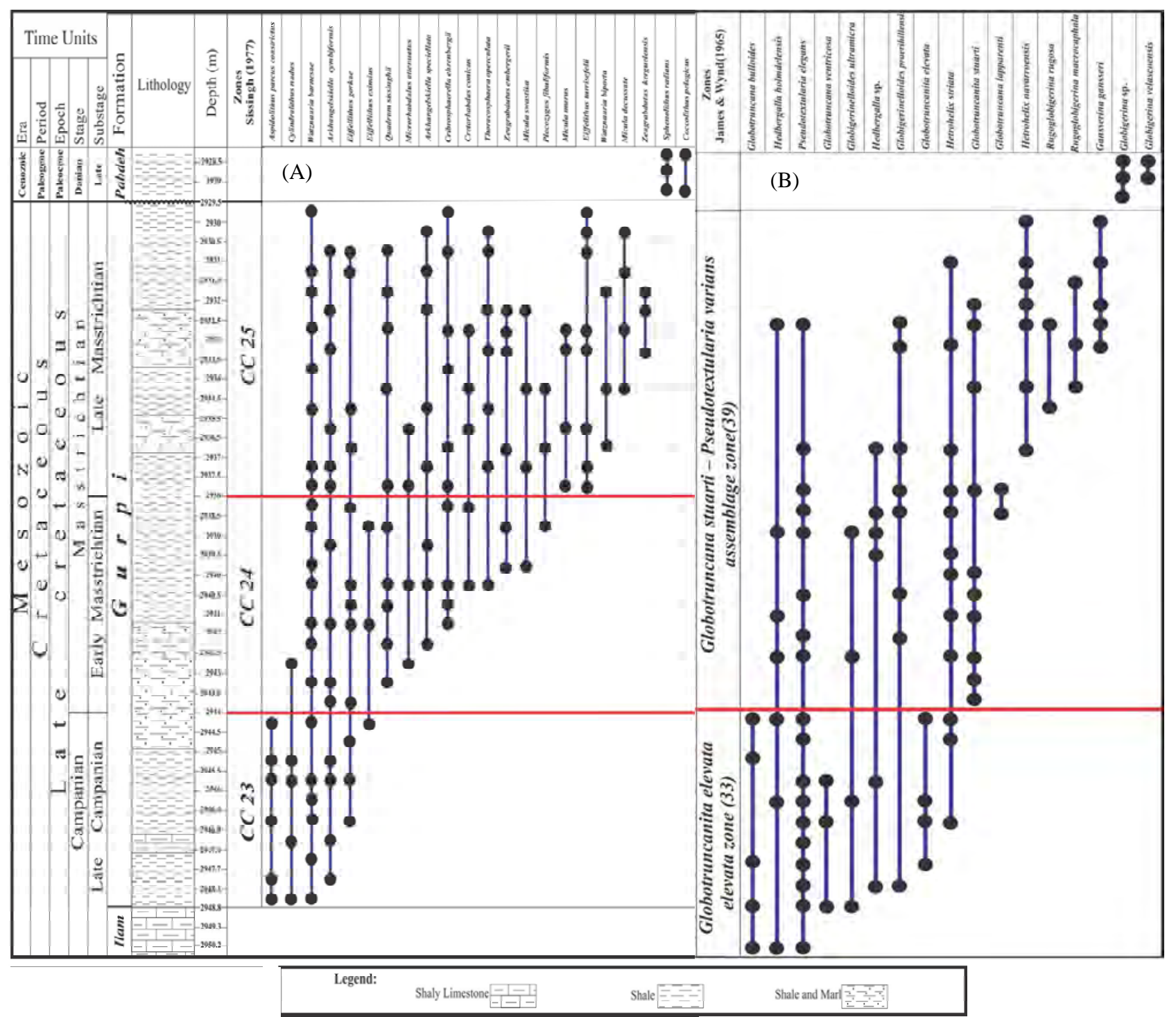

Figure 8. (A) Stratigraphic column and nannofissils distribution of the Gurpi Formation from the Well\# 10 at the Hendijan oil field; (B) Stratigraphic column and Planktonic foraminiferal distribution of the Gurpi Formation from the Well\# 10 at the Hendijan oil field.

3) Biozone No. 3-Arkhangelskiella cymbioformis zone (CC25) [10]: There are several definitions attached to the name this zone. Perch-Nielsen [45] defined it from the LO of the species now described as Reinhardtites levis to the FO of Micula murus or Nephrolithus frequens. This upper boundary provides a marker for low latitudes (M. murus) and one for high latitudes ( $N$. frequens). As at the Hendijan oil field Reinhardtites levis was not observed, the last unit recorded in the shale of the Gurpi Formation is the zone CC25 defined as the interval from the FO of Micula murus which is a good marker event in low latitudes to the LO of Cretaceous coccoliths or FO of the Sphenolithus radians and Coccolithus plagicus, assigned to the Late Maastrichtian [10,46]. A bio- event that is synchronous with the Cretaceous/Tertiary $(\mathrm{K} / \mathrm{T})$ Boundary Event in low latitude areas. Above this extinction are two successive blooms, Sphenolithus radians and Coccolithus plagicus. These blooms have been recorded in many low latitude areas, slightly above the K/T Boundary Event, in the lowermost Paleocene $[42,45,46]$. It represents an erosional surface disconformity as a result of Laramide orogenic phase activity. The thickness of this biozone is $8.5 \mathrm{~m}$ (from depth 2929.5 to $2938 \mathrm{~m}$ ) (Figure 8(A)).

\subsubsection{Biostratigraphy of Gurpi Fm. Using Planktonic Foraminifera}

Microfossils recognized within the Gurpi Formation 


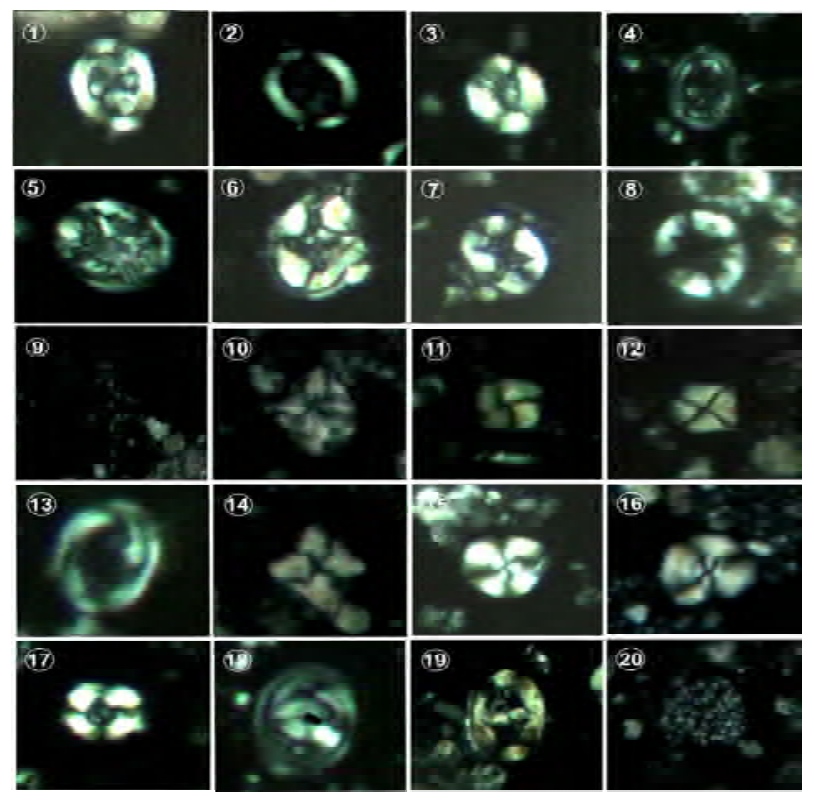

Figure 9. All figures in XPL light micrographs at 1250× magnification; 1. Arkhangelskiella cymbiformis; 2. Arkhangelskiella speciellata; 3. Aspidolithus parcus constrictus; 4. Cribrosphaerella ehrenbergii; 5. Cretarhabdus conicus; 6. Eiffellithus eximiu; 7. Eiffellithus gorkae; 8. Eiffelithus turrisefelli; 9. Microrhabdulus attenuatus; 10. Micula decussate; 11. Micula murus; 12. Micula swastika; 13. Placozygus fibuliformis; 14. Quadrum sissinghii; 15. Watznauria barnesae; 16. Watznaueria biporta; 17. Cylindralithus nudus; 18. Zeugrabdutus kerguelensis; 19. Zeugrabdutus embergerii; 20. Thoracosphaera operculata.

were dominantly planktonic (pelagic) foraminifera such as Gansserina gansseri, Globigerinelloides praerihillensis, Globigerinelloides ultramicra, Globotruncana bulloides, Globotruncana helvatica, Globotruncana lapparenti, Globotruncana ventricosa, Globotruncanita elevate, Globotruncanita stuarti, Hedbergalla holmdelensis, Hetrohelix navarroensis, Hetrohelix striata, Pseudotextularia elegans, Rugoglobigerina macrocaphala, Rugoglobigerina rugosa, Calcisphaerula innominata lata (Figure 10) which show two biozones depicted in Figure 8(B).

\subsubsection{Introducing Biozonation of Gurpi Fm. Based on Planktonic Foraminifers}

1) Biozone No. 1-Globotruncanita elevata elevata zone (33) [7]; associated microfossils are Globotruncana bulloides, Globotruncana ventricosa, Globigerinelloides ultramicra, Hedbergalla holmdelensis, Globigerinelloides praerihillensis, Pseudotextularia elegans. This biozone have been seen at lower part of the Gurpi with thickness of $5.3 \mathrm{~m}$ (from depth 2943 to $2948.3 \mathrm{~m}$ ) and the age is Late Campanian.

2) Biozone No. 2-Globotruncana stuarti-Pseudotextularia varians assemblage zone (39) [7]; associated microfossils are Globotruncana lapparenti, Globotrun-

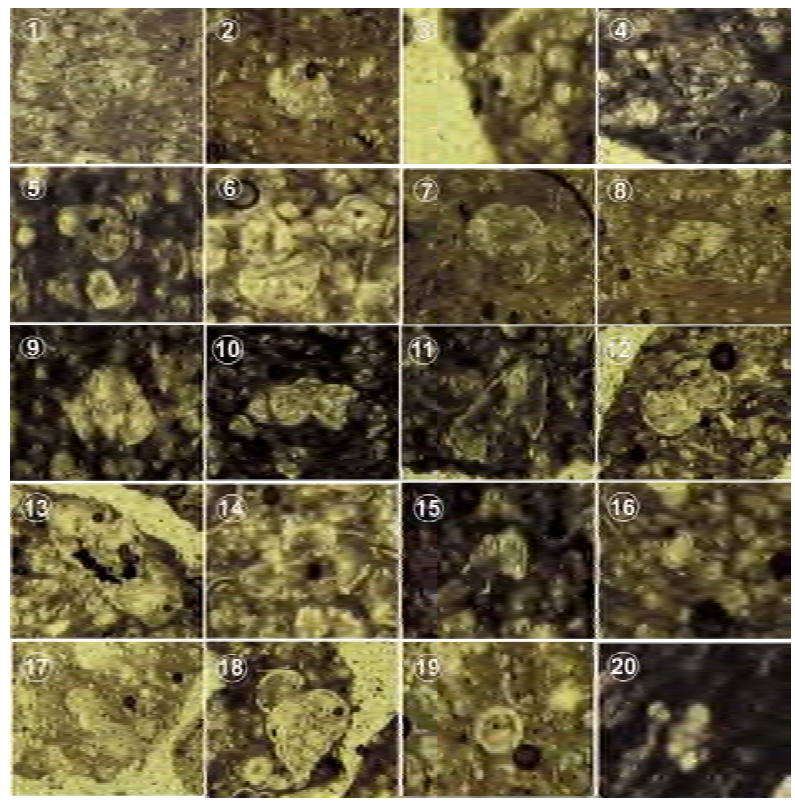

Figure 10. All figures in PPL light micrographs at 200× magnification; 1. Gansserina gansseri; 2,3. Hetrohelix navarroensis; 4. Hetrohelix striata; 5,6. Hedbergalla holmdelensis; 7. Rugoglobigerina rugosa; 8,9. Globotruncanita stuarti; 10. Globotruncana ventricosa; 11 . Globotruncanita elevata; 12 . Globotruncana helvatica; 13. Globotruncana lapparenti; 14,15. Globotruncana bulloides; 16. Globigerinelloides ultramicra; 17. Globigerinelloides praerihillensis; 18. Pseudotextularia elegans; 19. Calcisphaerula innominata lata; 20. Globigerinelloides algeriana.

canita stuarti, Hetrohelix striata, Gansserina gansseri. This biozone is observed at the upper part of the Gurpi Formation with thickness of $13.5 \mathrm{~m}$ (from depth 2929.5 to $2943 \mathrm{~m}$ ) and the age is Early to Late Maastrichtian.

\subsection{Pabdeh Formation}

\subsubsection{Biostratigraphy of Pabdeh Fm.}

Pabdeh Formation and its transition zone to Jahrum Formation (Jahrum-Pabdeh), with a thickness of $210 \mathrm{~m}$ at the Hendijan oil field overlies Gurpi Formation disconformably and is overlain by the Jahrum Formation comfortably and has an interfingering contact with it. This Formation consists of bluish gray, thin to medium bedded shale and marl and interbeds of argillaceous limestones (with purple shales) at lower part, dark gray shales and marls with intrebds of argillaceous limestone in the middle, and alternative layers of thinly bedded argillaceous limestone, shale and marl at the upper part (transition zone) [4]. The dominant microfacies in Pabdeh Formation are biomicrite. In this research, the Pabdeh Formation and its transition zone to the Jahrum Formation were studied. In this regards, 110 microscopic slides from these Formations were collected. Out of this, 18 genera and 42 species were determined and their range chart was plotted (Figure 11). The distribution of 


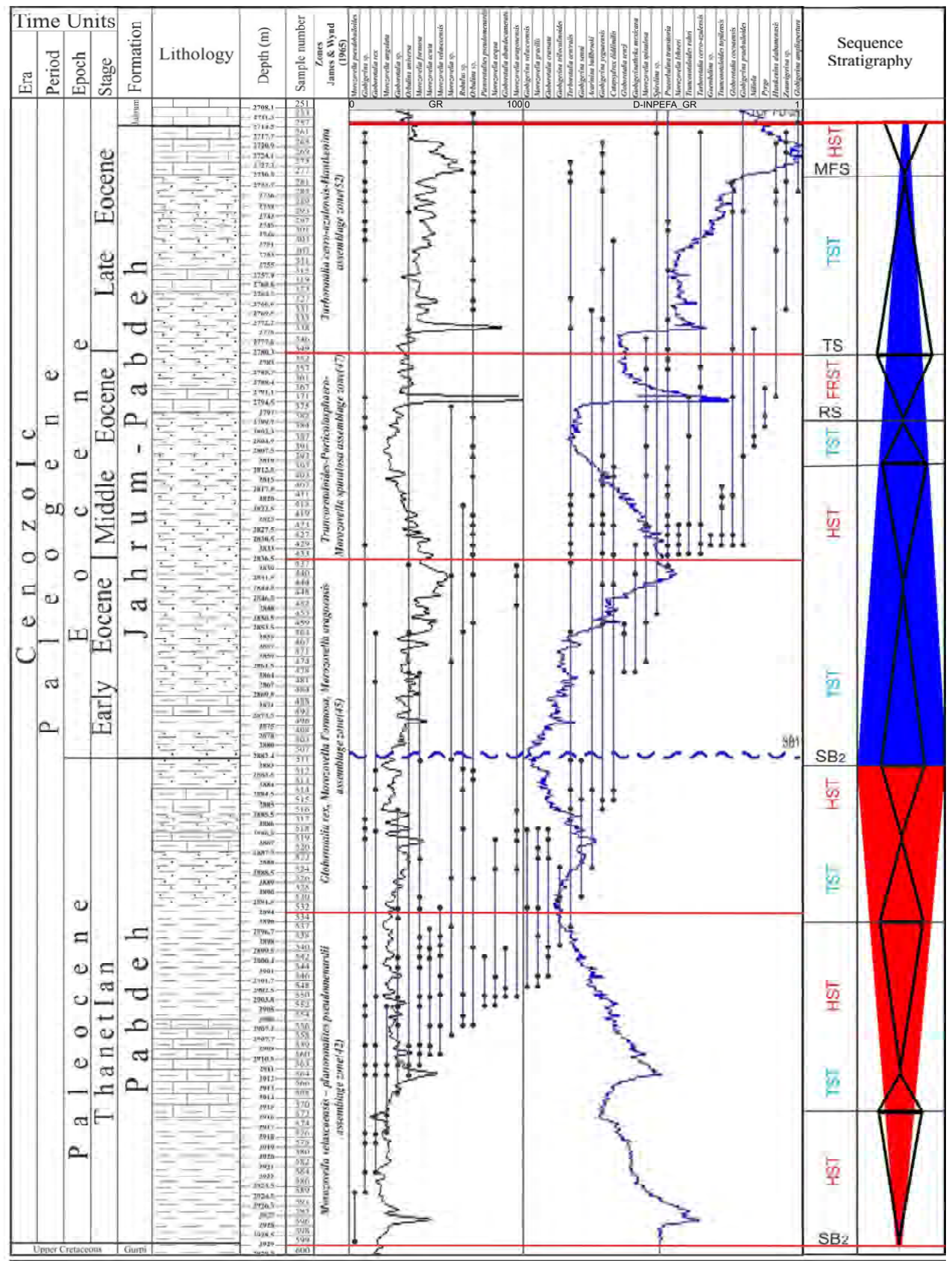

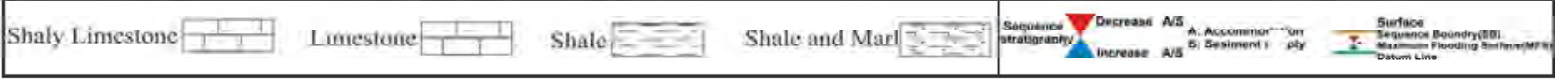

Figure 11. Stratigraphic column, Planktonic foraminiferal distribution and sequence stratigraphy of the Pabdeh and its transition zone (Jhrum-Pabdeh) from the Well\# 10 at the Hendijan oil field. 
foraminifera species indicates that there are 4 biozones at the Hendijan oil field. On this basis, the age of sedimenttation of Pabdeh Formation can be suggested to be from late Paleocene (Thanetian) to lower Eocene and its Transition zone can be suggested to be from Lower Eocene to Late Eocene. Microscopic studies and lithological variations of these Formations offer a basin margin environment for Pabdeh Formation and fore slope to basin margin environment for its transition zone. Index species recognizing at this Formation are as below:

Acarinina bullbrooki, Catapsydrax dissimilis, Globigerina ampliapertura, Globigerina praebulloides, Globigerina triloculinoides, Globigerina velascoensis, Globigerina yeguaensis, Globigerina senni, Globigerinatheka Mexicana, Globigerina sp., Globorotalia abandocamerata, Globorotalia crassata, Globorotalia cocoaensis, Globorotalia renzi, Globorotalia rex, Globorotalia sp., Guembelina sp., Hantkenina alabamennsis, Morozovella acuta, Morozovella aequa, Morozovella angulata, Morozovella aragonensis, Morozovella formosa formosa, Morozovella gracilis, Morozovella lehneri, Morozovella spinulosa, Morozovella pseudobulloides, Morozovella velascoensis, Morozovella sp., Miliola, Orbulina universa, Orbulina sp., Planorotalites pseudomenardii, Praeorbulina transitoria, Pyrgo, Robulus sp., Spirolina sp., Turborotalia centralis, Turborotalia cerro-azulensis, Truncorotaloides topilensis, Truncorotaloides rohri, Zeauvigerina sp. (Figures 12 and 13).

\subsubsection{Introducing Biozonation of Pabdeh Fm. and Its Transition Zone (Jahrum Fm.)}

1) Biozone No. 1-Morozovella velascoensis-planorotalites pseudomenardii assemblage zone (42) [7]: This biozone includes the all sediments of Late Paleocene in the studied stratigraphic section. The thickness of this biozone is $35.5 \mathrm{~m}$ and its index microfossils include: Morozovella velascoensis, planorotalites pseudomenardii, Globorotalia elongata, Morozovella Formosa, Morozovella gracilis, Morozovella aequa.

2) Biozone No. 2-Globorotalia rex, Morozovella Formosa, Morozovella aragoensis assemblage zone (45) [7]: The thickness of this biozone is $62 \mathrm{~m}$ and its microfossils include: Globorotalia rex, Morozovella Formosa, Morozovella aragoensi which indicate the age of Early Eocene.

3) Biozone No. 3-Truncorotaloides-Porticulasphaera Morozovella spinulosa assemblage zone (47) [7]: This biozone includes the all sediments of Middle Eocene in the studied stratigraphic section. The thickness of this biozone is $52 \mathrm{~m}$ and its microfossils include: Truncorotaloides spp., Porticulasphaera spp., Morozovella spinulosa, Morozovella lehneri, Morozovella aragoensis, Globorotalia centralis, Hantkenina sp., Catapsydrax sp.

4) Biozone No. 4-Turborotalia cerro-azulensis-Hant-

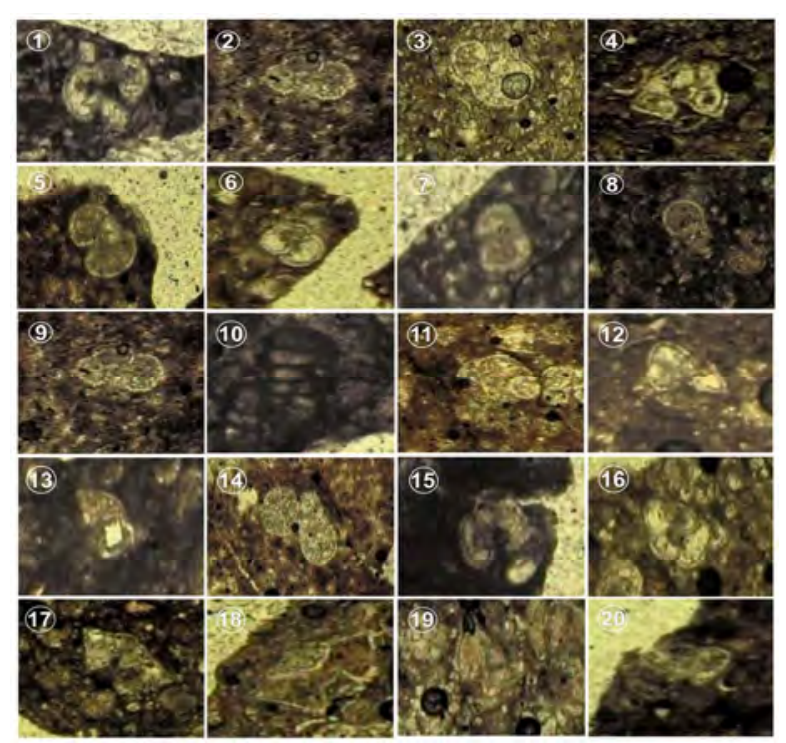

Figure 12. All figures in PPL light micrographs at $200 \times$ magnification; 1. Globigerina ampliapertura; 2. Globigerina praebulloides; 3. Globigerina triloculinoides; 4. Globigerina velascoensis; 5. Globigerina yeguaensis; 6. Globigerina senni; 7. Globigerinatheka Mexicana; 8. Globigerina sp.; 9. Globigerina praebulloides; 10. Guembelina sp.; 11. Zeauvigerina sp.; 12. Turborotalia cerro-azulensis; 13 . Truncorotaloides topilensis; 14. Truncorotaloides rohri; 15. Turborotalia centralis; 16. Morozovella acuta; 17. Morozovella aequa; 18. Morozovella angulata; 19. Morozovella aragonensis; 20. Morozovella formosa formosa.

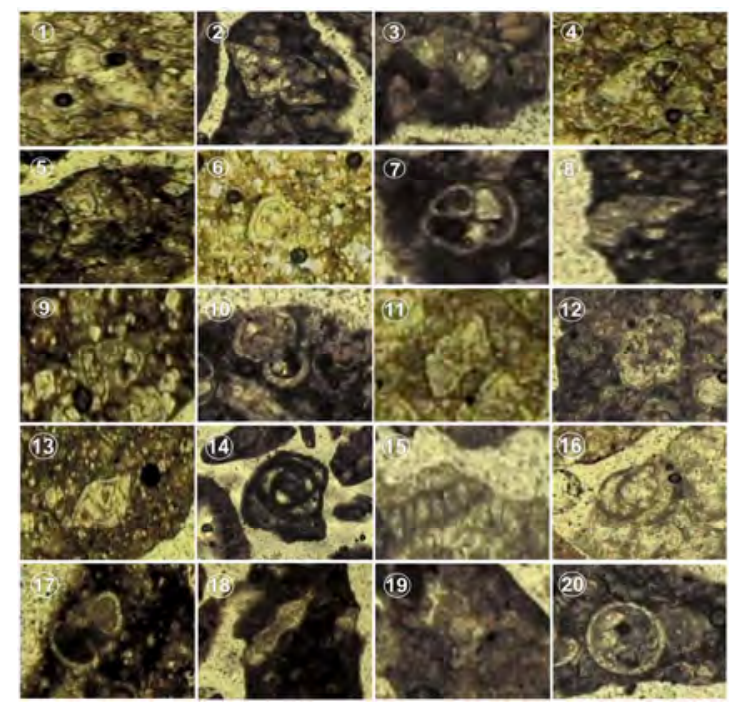

Figure 13. All figures in PPL light micrographs at 200× magnification; 1. Morozovella gracilis; 2. Morozovella lehneri; 3. Morozovella spinulosa; 4. Morozovella velascoensis; 5. Globorotalia abandocamerata; 6. Globorotalia crassata; 7. Globorotalia cocoaensis; 8. Globorotalia renzi; 9. Globorotalia rex; 10. Praeorbulina transitoria; 11. Planorotalites pseudomenardii; 12. Catapsydrax dissimilis; 13. Robulus sp.; 14. Miliola; 15. Spirolina sp.; 16. Pyrgo williamsoni; 17. Acarinina bullbrooki; 18, 19. Hantkenina alabamennsis; 20. Orbulina sp. 
kenina assemblage zone (52) [7]: This biozone includes the all sediments of Late Eocene in the studied stratigraphic section. The thickness of this biozone is $72 \mathrm{~m}$ and its associated microfossils are: Turborotalia cerro, Hantkenina sp., Globorotalia centralis, Catapsydrax sp., Globigerinatheka sp.

\subsubsection{Gurpi and Pabdeh Formations Boundary}

At the Hendijan oil field the boundary between Gurpi and Pabdeh Formations is of disconformity type. Considering lithological similarity of both Formations, determining of this unconformity from field observations is not possible and it is done by means of microscopic studies and microfossil recognition. The boundary between the two Formations, at the Hendijan oil field, rests at the base of purple shale. In this region, the recognition of Globorotalia (Morozovella) velascoensis, which is attributed to lower part of the Pabdeh Formation, separates the two formations. This bed represents a non-depositional (epirogeny) period from the Late Maastrichtian to the end of Early Paleocene (Figure 14).

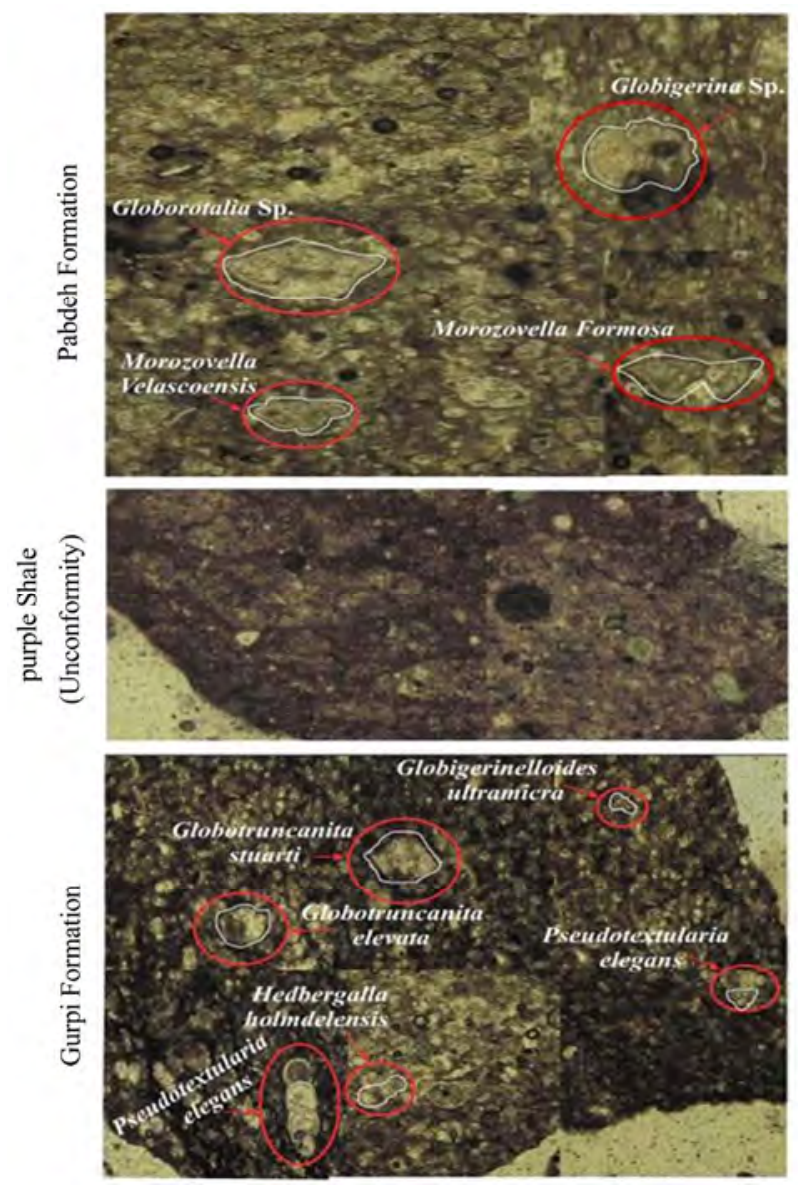

Figure 14. Microfacies criteria observed in microscopic examination of Gurpi and Pabdeh Formations accompanying with planktonic microfossils and the purple Shale as a factor of Unconformity.

\subsubsection{Sequence Stratigraphic Description of the Pabdeh and Jahrum-Pabdeh Fms. in Well \#10 of the Hendijan Oilfield Using Dynamic-INPEFA Curves of Cyclolog Software}

The study of vertical variations in the facies of Pabdeh Formation and its teansition zone has mainly shown one sedimentary sequence (the third class cycle) including 5 subsequences. The lower boundary of Pabdeh Formation is identified by purple shale from Gurpi formation (SB2). In the relative static state of sea level HST facies with the thickness of $49 \mathrm{~m}$ includes alternation of pelagic facies and redeposited limestones. TST facies with the thickness of $174 \mathrm{~m}$ includes mudstone as well as Globrotalia, Globigerina bioclast wackstone. Maximum flooding surface (MFS) of the sea is characterized by thin bedded dark shale facies. The main result can be inferred of different subsequences in Pabdeh Formation is that there were fluctuations with sea level. The existence of benthonic bioclast as well as the mixture of benthonic environment and platform facies indicates the high rate of deposition which causes tempestite deposits, carbonate slumping from platform margin with steep slope and its deposition in the sea depth [47].

\subsubsection{Depositional Environment and Microfacies of Pabdeh and Jahrum-Pabdeh Fms.}

The interpretation of depositional processes and sedimentary paleoenvironment of the Pabdeh Formation is done by lithofacies and biofacies and, in particular, its microfacies. The following microfacies criteria which are observed in microscopic examination of the Pabdeh Formation have shown a deep marine environment [31, 48-51] and a platform environment for its transition zone. Microscopic samples determined that the identified facies of the Pabdeh Formation have been all deposited in the sea depth. They can be divided into two groups: pelagic (Group A) and calciturbidite (Group B) facies. Calciturbidites can be seen as interbedded in pelagic facies especially within transition zone.

\section{1) Pelagic Microfacies}

A1—Mudstone/Shale

Approximately this facies totally includes lime mud in black shale. Black shale facies in the sequence of the Pabdeh Formation has relatively great expansion. It is mainly seen in alternation with globigerina bioclast mudstone and globrotalia. Bioturbation is another feature of this facies. Mudstone/shale facies has been seen with thinbedded lime shale facies (Figure 15(A)).

A2-Globrotalia, Globigerina Bioclast Mudstone

In this facies less than $5 \%$ of skeletal allochem from Globigerina and Globrotalia family exists in a micritic matrix. This facies has been deposited in a low order environment of open sea and its lithostratigraphic con- 

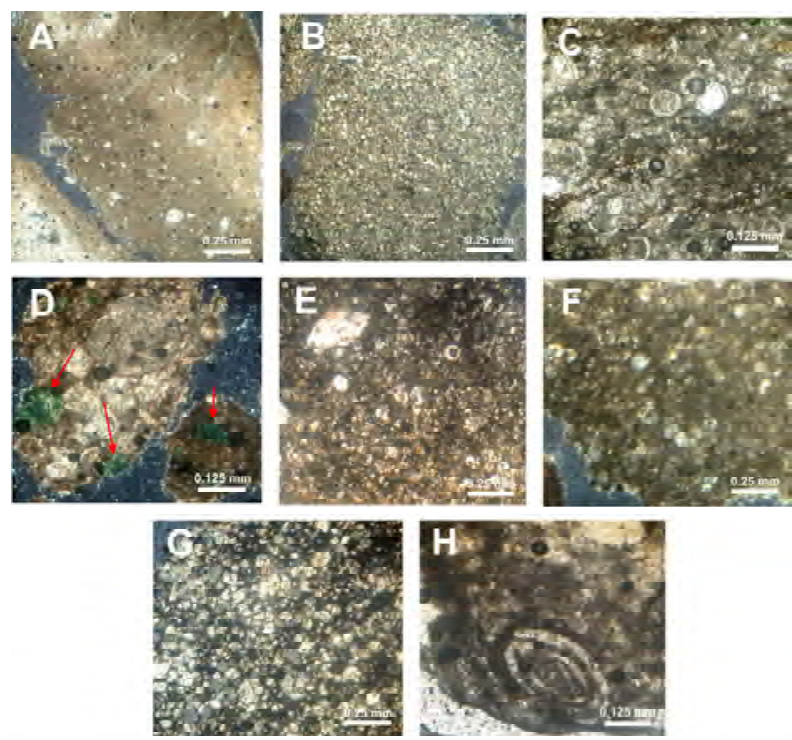

Figure 15. Microfacies of the Pabdeh Formation at the Hendijan oil field; A: mudstone/gray shale (A1 facies); B) Globrotalia-Globegerina bioclast mudstone (A2 facies); C) Globrotalia-Globegerina bioclast wackestone (A3 facies); D) Glouconitic Globegerina bioclast packstone (A4 facies); (E)-(G) bioclast wackestone (B1 facies); (H) Intraclastic peloiedal bioclast wackestone (B2 facies).

stitutes includes thin to medium-bedded dark lime shale (Figure 15(B)).

A3-Globrotalia, Globigerina Bioclast Wackstone

About $40 \%$ of this facies is Globrotalia, Globigerina bioclast. The matrix of this facies is gray micrite and also a low percent (less than 5\%) of pellet is found. In this facies a low percent of glauconitization in foraminifera's pores has been seen (Figure 15(C)).

\section{A4-Glauconit Globigerina Bioclast Packstone}

Over $55 \%$ of the sample mass of this facies consists of the species such as globigerina and globrotalia in a micritic matrix. The mentioned facies includes $10 \%-15 \%$ glauconitization in the pores of plankton microfossils (Figure 15(D)).

The existence of planktonic bioclasts related to deep sea such as Globigerina, Globrotalia and abundant micrite indicates the deposition of this group in deep sea environment [22].

\section{2) Calciturbidite Facies}

\section{B1-Bioclast Wackstone}

In this facies bioclasts from Nummulite and Milliolide have been seen in a micritic matrix. In some similar samples, $20 \%$ to $35 \%$ of the facies has been dolomitized. There are also $25 \%$ to $40 \%$ of planktonic microfossils in the sample such as Globigerina and Globrotalia. This facies has been deposited in the form of calciturbidite in the sea depth and interbedded in pelagic limes and shales. It is important to be mentioned that the lower boundary of calciturbidite with shales is abrupt (Figures 15(E) and
(F)).

B2-Intraclastic Peloidal Bioclast Wackstone

In this facies about $30 \%$ of pellet, $15 \%$ of intraclasts and $25 \%$ of skeletal allochem from milliulide family with debris of planktonic shell in a micritic matrix have been seen (Figure 15(H)).

Existence of benthonic bioclasts such as Milliolide and Nummulite in calciturbidite facies (B1 and B2) indicates deposition in a platform environment. The indication that pelagic and turbidite facies are interbedded and the mixture of planktonic and benthonic grains in calciturbidites shows the high rate of deposition (Figure 16).

\section{CONCLUSION}

In this study, the Early Cenomanian-Late Eocene deposits of the Sarvak, Ilam, Gurpi, Pabdeh and JahrumPabdeh Formations at the Hendijan oil field were studied in detail with regard to microbiostratigraphy, microfacies, stratigraphy, and geochemistry. Our data provide insights into the palaeoenvironmental evolution and sea-level fluctuations using D-INPEFA curves. Planktonic foraminifera and calcareous nannofossils which are suitable for subdivided biostratigarphy, since they are abundantly planktonic, rapidly evolving and largely cosmopolitan, were used for biozonation leading to accurate time scale of each formation. Sarvak and Ilam Formations have been formed of marly limestone with thinner interbeds of marl and limestone. Because of the similar litology of these Formations, recognition of boundary between Ilam and Sarvak Formations was done using geochemical analysis (oxygen and carbon isotopes). 18 genera and 26 species and 10 genera and 6 species of planktonic foraminifera were determined in Sarvak and Ilam Formations respectively. Based on the obtained foraminifera, Sarvak Formation is Early Cenomanian to Turonian and Ilam Formation is Campnian in age. Based on detailed sedimentological analysis over the Sarvak Formation, four facies associations including tidal flat,

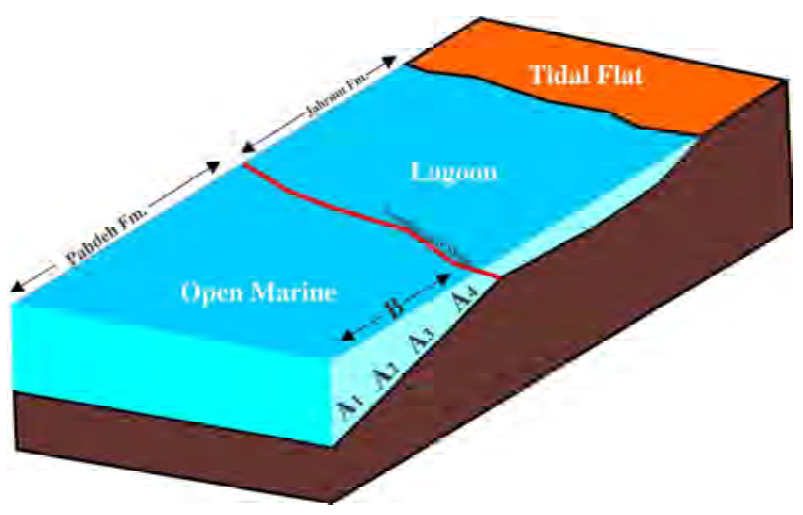

Figure 16. Sedimentary environment model of the Pabdeh formation A: pelagic facies B: calciturbidite facies. 
barrier, lagoon and open marine have been recognized. The detailed microfacies analysis and sedimentological criteria suggest that the Sarvak was deposited in a carbonate ramp. Sequence stratigraphy was evaluated based on INPEFA curves resulting from Gamma ray logs. Out of this, two-third-order sequences in the study section were identified for Sarvak Formation. Gurpi Formation has been formed of dark shales with thinner interbeds of marl. As a result of the correlation between 8 genera and 16 species of planktonic foraminifera and 13 genera and 19 species of calcareous nannofossils determined in this Formation, the Gurpi Formation is Late Campnian to Late Maastrichtian in age. In addition, peresence index species of low latitude in Gurpi Formation shows that this sedimentary basin was located in low latitude at the time of sedimentation. Pabdeh and Jahrum-Pabdeh Formations have been formed of shale and marl with interbeds of argillaceous limestones and shaly limestone respectively. 18 genera and 42 species of planktonic foraminifera were determined in these Formations. Based on the obtained foraminifera, Pabdeh Formation is Thanetian and Jahrum-pabdeh Formation is Early to Late Eocene in age. Microfacies study indicated 6 pelagic and calciturbidite microfacies deposited in deep marine. Calciturbidite facies were formed during sea level highstand, when high rate of carbonate production resulted in transportation of carbonate sediment in deep sea. Sequence stratigraphy study shows that Pabdeh and Jahrum-Pabdeh Formations consist of one main depositional sequence.

\section{ACKNOWLEDGEMENTS}

The authors express their thanks to Shahid Chamran University authorities. We are indebted to Mr. M. H. Hosseini Farzad, chairman of the Geology Department of the National Iranian Offshore Oil Company (NIOOC), for assistance in our fieldwork and sampling. We are also indebted to Mr. A. Mansour and Dr. H. Pourkaseb (University of Shahid Chamran) for their fruitful discussions and encouragements. We thank two anonymous reviewers for their constructive comments that helped used improve this paper.

\section{REFERENCES}

[1] Edgell, H.S. (1996) Salt tectonism in the Persian Gulf Basin. Geological Society, London, Special Publications, 100, 129-151. http://dx.doi.org/10.1144/GSL.SP.1996.100.01.10

[2] Konyuhov, A.I. and Maleki, B. (2006) The persian gulf basin: Geological history, sedimentary formations, and petroleum potential. Lithology and Mineral Resources, 41, 344-361. http://dx.doi.org/10.1134/S0024490206040055

[3] Alavi, M. (2004) Regional stratigraphy of the Zagros fold-thrust belt of Iran and proforland evolution. American Journal of Sciences, 304, 1-20. http://dx.doi.org/10.2475/ajs.304.1.1

[4] Sherkati, S. and Letouzey, J. (2004) Variation of structural style and basin evolutionin the central Zagros Izeh zone and Dezful Embayment, Iran. Marine and Petroleum Geology, 21, 535-554.

[5] Motiee, H. (1994) Geology of Iran: Stratigraphy of Zagros. Geological Survey of Iran, 536 p.

[6] Afshar Harb, A. (2001) Petroleum Geology chapters. Tehran University.

[7] James, G.A. and Wynd, J.G. (1965) Stratigraphic nomenclature of Iranian Oil Consortium Agreement area. American Association of Petroleum Geologists Bulletin, 49, 2182-2245.

[8] Rahaghi, A. (1978-1983) Stratigraphy and Fauna Assemblage of Palaocene-Lower Eocene in Iran. N.I.O.C.puble. No. 10, 79 p.

[9] Farzipour-Saein, A., Yassaghi, A., Sherkati, S. and Koyi, H. (2009) Mechanical stratigraphy and folding style of the Lurestan region in the Zagros Fold-Thrust Belt, Iran. Journal of the Geological Society, 166, 1101-1115. http://dx.doi.org/10.1144/0016-76492008-162

[10] Sissingh, W. (1977) Biostratigraphy of cretaceous calcareous nannoplankton. Geol En Mijnbouw, 36-65.

[11] Alegret, L. and Thomas, E. (2001) Upper Cretaceous and lower benthic foraminifera from north eastern Mexico. Micropalaeontology, 47, 269-316. http://dx.doi.org/10.2113/47.4.269

[12] Gibson, T.G., Bybell, L.M. and Owens, J.P. (1993) Latest Palaocene lithologic and biotic events in neritic deposits of south-western New Jersey. Palaeooceanography, 8, 495-515.

[13] Khosrotehrani, Kh., Afghah, M. and Ahmadi, V. (2005) Microbiostratigraphy and microfacies study of Jahrum formation in North \& South east shiraz. Journal of Applied Geology, 1, 1-12.

[14] Loeblich, A.R. and Tappan, H. (1989) Foraminifera genera and their classification. Van Nostrand Reinhold publication Company, New York, Vol. 1-2.

[15] Adabi, M.H. (2004) Sedimentary geochemistry. Arian Zamin, Tehran.

[16] Anderson, T.F. and Arthur, M.A. (1983) Stable isotopes of oxygen and carbon and their application to sedimentologic and paleoenvironmental problems. In: Stable Isotopes in Sedimentary Geology, Society of Economic Paleontology and Mineralogy, Short Course 10, Section 1.1-1.151.

[17] Adabi, M.H. (1996) Sedimentology and geochemistry of Upper Jurassic (Iran) and Precambrian (Tasmania) carbonates. Ph.D. Thesis, University of Tasmania, Australia, $407 \mathrm{p}$.

[18] Rao, C.P. and Adabi, M.H. (1992) Carbonate minerals, major and minor elements and oxygen and carbon isotopes and their variation with water depth in cool, temperate carbonates, western Tasmania, Australia. Marine Geology, 103, 249-272. http://dx.doi.org/10.1016/0025-3227(92)90019-E

[19] Milliman, J.D. (1974) Marine Carbonates. Springer-Ver- 
lag, New York.

[20] Mial, A.E. (1997) Geology of stratigraphic sequence. Springer-Varelag, Berlin, 433 p.

[21] Emery, D. and Myers, K.J. (2005) Sequence Stratigraphy. Blackwell publ., London, 425 p.

[22] Flugel, E. (2004) Microfacies of carbonate Rocks. Analysis, Interpretation and Application, Springer Verlag, New York.

[23] Simo (Toni), J.A., Lehmann, P.J. and Creek, J.R. (2000) Diagenetic history of Pipe Reef, Solurian, North Centeral Indian, U.S.A. Journal of Sedimentar-Research, 70, 937951.

[24] Adachi, N., Ezaki, Y. and Liu, J. (2004) The origins of peloids immediately after the end-Permian extinction, Guizhou Province, South China. Sedimentary Geology, 164, 161-178. http://dx.doi.org/10.1016/j.sedgeo.2003.10.007

[25] Premoli-Silva, I. and Sliter, W.V. (1994) Cretaceous planktonic foraminiferal biostratigraphy and evolutionary trends from the Bottaccione section. Paleontographia Italica, Gubbio.

[26] Brasier, M.D. (1995) Fossil indicators of nutrient levels. 1: Eutrophication and climate change. In: Bosence, D.W. and Allison P.A., Eds., Marine palaeoenvironmental analysis from fossils, Geological Society Special Publication, 83, 113-132.

[27] Luciani, V. and Cobianchi, M. (1999) The Bonarelli level and other black shales in the Cenomanian-Turonian of the northeastern dolomites (Italy): Calcareous nannofossil and foraminiferal data. Cretaceous Research, 20, 135-167. http://dx.doi.org/10.1006/cres.1999.0146

[28] Birkeland, C. (1987) Nutrient availability as a major determinant of differences among coastal hardsubstratum communities in different regions of the tropics. In: Birkeland, C., Ed., Comparison between Atlantic and Pacific tropical marine coastal ecosystems: Community structure, ecological processes, and productivity. UNESCO Reports in Marine Science.

[29] Heckel, P.H. (1972) Recognition of ancient sedimentary environments.

[30] Sanders, D. and Hofling, R. (2004) Carbonate deposition in mixed siliciclastic carbonate environments on top of an orogenic wedge (Late Cretaceous, Northern Calcareous Alps, Austria). Sedimentary Geology, 137, 127-146.

[31] Flugel, E. (1982) Microfacies analysis of Limestones. Springer-Verlag, Berlin. http://dx.doi.org/10.1007/978-3-642-68423-4

[32] Ross, D. and Skelton, P.W. (1993) Rudist formations of Cretaceous: A palaeoecological, sedimentological and stratigraphical review. Sedimentology Review.

[33] Wilson, V.P. (1975) Carbonate facies in geologic history. Springer-Verlag, New York. http://dx.doi.org/10.1007/978-1-4612-6383-8

[34] Lakhdar, R., Soussi, M., Ben Ismail, M. and Rabet, A. (2006) A Mediterranean Holocene restricted coastal lagoon under arid climate: Case of the sedimentary record of Sabkha Boujmel (SE Tunisia). Palaeogeography, Pa- laeoclimatography, Palaeoecology, 241, 177-191.

[35] Bachmann, M. and Harsch, F. (2006) Lower Cretaceous carbonate platform of the eastern Levant (Galilee and the Golan Heights): Stratigraphy and second-order sea-level change. Cretaceous Research, 27, 487-512. http://dx.doi.org/10.1016/j.cretres.2005.09.003

[36] Sandulli, R. (2004) The barremian carbonate platform strata of the Montenegro Dinarids near Podgorica, a cyclostratigraphic study. Cretaceous Research, 25, 951-967. http://dx.doi.org/10.1016/j.cretres.2004.09.002

[37] Shinn, E.A. (1983) Tidal flat environment. In: Scholle, P.A., Bebout, G. and Moore, C.H., Eds., Carbonate Depositional Environments, AAPG Memoir, 33, 171-210.

[38] Messe, J.P., Fenerci, M. and Pernarcie, E. (2003) Palaeobathymetric reconstruction of peritidal carbonates late Barremian, Urgonian, sequences of Provence (SE France). Palaeogeography, Palaeoclimatology, Palaeoecology, 200, 65-81. http://dx.doi.org/10.1016/S0031-0182(03)00445-0

[39] Folk, R.L. (1974) Petrology of sedimentary rocks. 2nd Edition, Hemphill, 182 p.

[40] Wright, V.P. (1992) A revised classification of limestones, Sedimentary Geology, 76, 177-185. http://dx.doi.org/10.1016/0037-0738(92)90082-3

[41] Bown, P.R. and Young, J.R. (1998) Techniques. In: Bown, P.R., Ed., Calcareous nannofossil biostratigraphy, Chapman and Hall, London, 16-28. http://dx.doi.org/10.1007/978-94-011-4902-0_2

[42] Burnett, J.A. (1998) Upper Cretaceous. In: Bown, P.R. Ed., Calcareous nannofossil biostratigraphy, Chapman and Hall, London, 132-200.

http://dx.doi.org/10.1007/978-94-011-4902-0_6

[43] Cepek, P. and Hay, W.W. (1970) Zonation of the upper cretaceous using calcareous nannoplankton. Palaobotanik, 3, 333-400.

[44] Crux, L.A. (1982) Upper Cretaceous (Cenomanian to Campanian) calcareous nannofossils. In: Lord, A.R., Ed., A Stratigraphical Index of Calcareous Nannofossils. British Micropal. Soc., 81-135.

[45] Perch-Nielsen, K. (1981) New maastrichtian and paleocene calcareous nannofossils from Africa, Denmark, the USA and the Atlantic and some Paleocene linages. Eclogae Geologicae Helvetiae, 74, 7-23.

[46] Perch-Nielsen, K. (1985) Mesozoic calcareous nannofossils. In: Bolli, H.M., Saunders, J.B. and Perch-Nielsen, K. Eds., Plankton Stratigraphy, Cambridge Earth Science, Cambridge Univ. Press, 329-426.

[47] Schalger, W., Reijmer, J.J.G. and Droxler, A. (1994) Highstand shedding of carbonate platforms. Sedimentary Research, 64, 270-281.

[48] Jenkyns, H.C. (1986) Pelagic Environments. In: Reading, H. G., Ed., Sedimentary Environments and Faces, 2nd Edition, Blackwell Scientific Publication, 343-397.

[49] Reading, H.G. (1996) Sedimentary environments: Processes, facies and stratigraphy. 3rd Edition, Blackwell Science, Oxford, $688 \mathrm{p}$.

[50] Einsele, G. (2000) Sedimentary Basins, Evolution, Facies and Sediment Budget. 2nd Edition, Springer-Verlag, 792 p. 
[51] Raymond, L.A. (2002) Petrology: The study of igneous, sedimentary and metamorphic rocks. 2nd Edition, Mc-
Graw Hill, New York, 720 p. 